Al-Fikra: Jurnal Ilmiah Keislaman, Vol. 5, No. 1, Januari-Juni 2006

\title{
PEMIKIRAN POLITIK ISLAM: Tinjauan Sejarah Awal Islam Klasik
}

\author{
Alimuddin Hassan Palawa \\ Fakultas Tarbiyah dan Keguruan UIN Suska Riau
}

\begin{abstract}
Islamic Political Ideology: A Historical overview of the beginning of classical Islam: Muslim are divided into three ideologies. Firstly, the ideology which claims that Islam is a religion which regulates the totality of life and finds out solutions to all problems including problems in politics. Secondly, the ideology that claims Islam is simply a religion that has no connection with politics at all. Thirdly, the ideology that claims there is no political and constitutional systems in Islam, but Islam has ethical values for the life of the nation. There is no doubt that under the leadership of the Prophet Mohammad (peace be up on him) the Arab people made a great breakthrough both in sophisticated social and political lives. When the social structure was already set up under the leadership of the Prophet and was then developed by the first caliphs to provide the principles of arranging a world empire, it was considered modern in terms of time and place. It was modern because of high commitment of people and the participation of ordinary people as the members of the community and the openness of their leaders to be evaluated on universal basis which symbolized the leadership which were not based on descent.
\end{abstract}

Keywords : politics, Islamic Ideology, community.

\section{Pendahuluan}

Kelahiran Islam lewat pewahyuan (selama rentang tahun 610-632) pada figur Nabi Muhammad saw. dinilai sangat tepat ruang dan pas waktu. ${ }^{1}$ Sehingga, dalam waktu relatif singkat (hanya 23 tahun lamanya) Nabi

${ }^{1}$ Disebut "tepat-ruang" karena Mekkah dan Madinah (jazirah Arab umumnya) relatif "jauh" dari jangkauan kekuasaan dan pertikaian dari dua negara adi-kuasa: Kekaisaran Romawi dan Khousru Persia. Dikatakan "pas-waktu" karena saat itu kedua negeri super power tersebut semakin melemah akibat peperangan yang berkesenantiasa antara mereka. Sehingga, menurut J.J. Saunders, "andaikata Islam lahir seabad sebelumnya, maka kaisar Yustianus (Romawi) yang kuat pada era itu akan menghalangi penyebaran Islam. Apabila seabad setelahnya, barangkali Arabia telah memeluk agama Kristen karena kekuatan Byzantium dan Persia telah pulih kembali." Pada bagian lain, Saunders melanjutkan pengandaiannya, "andaikan saja Abraham berhasil benguasi Mekkah, maka seluruh jazirah Arab akan terbuka untuk penerobosan Kristen dari Byzantium. Akibatnya, tanda Salib akan menjulang tinggi di atas Ka'bah; dan Muhammad mungkin akan mati sebagai pastur atau pendeta." Lihat, J.J. Saunders, A History of Medieval Islam, (London: Reutledge, 1965), hlm. 14-15 dan 36-37. Ini hanya sekedar pengandaian. Dan sejarah tidak dapat diajak berandai-andai, disebut sejarah karena ia adalah peristiwa masa lalu yang real terjadi dan memiliki fakta dan data kuat dan akurat. 
Muhammad saw. berhasil dengan sangat mencengangkan dalam mengemban tugas dan misi dari Allah. Sepeninggalan Nabi Muhammad saw (w. 632) keberhasilan dalam Islam dilanjutkan pula dengan gemilang oleh Khulafa alRasyidin. Agama Islam yang masih "remaja" ini merambah ke mana-mana untuk melakukan "pembebasan" (futuhat) di propinsi-propinsi jajahan dua adikuasa: Kekaisaran Romawi dan Khousru Persia, seperti Syiria, Irak, Mesir, dan bahkan belakangan kedua ibukota negeri super power tersebut juga mampu ditaklukkan oleh tentara Islam. ${ }^{2}$ Dengan jatuhnya kota Iskandaria pada 651 di tangan jenderal Amru bin 'Ash menandai rampungnya penaklukan Islam terhadap Timur Dekat, sekaligus berakhirnya kekuasaan Persia dan Byizantium di wilayah tersebut. ${ }^{3}$ Kurang dari lima puluh tahun berikutnya tentara Islam menaklukan Spanyol di belahan Barat dan India di Timur. ${ }^{4}$

Kejayaan politik dan kesukesesan spektakuler ekspansi militer Islam di atas menjadi salah satu karakteristik agama Islam pada awal-awal penampilannya. ${ }^{5}$ Untuk itu, wajar sekali kalau W. Motgemory Watt, misalnya melihat secara umum, "sepanjang sejarah manusia, agama selalu terlibat secara intens pada keseluruhan hidup manusia dalam masyarakat, termasuk dalam

${ }^{2}$ Lihat, Marshall G.S. Godgson, The Venture of Islam Conscience and History in a World Civilization, (New York \& London: The Univrsity of Chicago Press, 1961), hlm. 197-206

${ }_{3}^{3}$ Setidaknya, menurut Majid Fakhri, ada dua alasan kenapa penaklukan Islam begitu mudah dilancarakan: pertama, upaya perluasan dilakukan oleh kekaiasaran Romawi, Heraklius pada 610 mengakibatkan timbulnya pertarungan dahsyat antara orang-orang Persia dan Byzantium yang sebelumnya telah berjibaku dalam peperangan panjang guna menancapkan pengaruh militer mereka di Timur Dekat. Peristiwa perang berkepanjangan di antara mereka mengakibatkan melemahnya kekuatan masing-masing, sehingga tentara Islam dengan mudah mencatat serangkai kemenangan demi kemenangan dari kedua bala tentara yang jumlahnya lebih banyak dan sangat terlatih; dibandingkan dengan tentara Islam yang jumlahnya sedikit, ditambah belum berpengalaman dalam medan peperangan besar. Kedua, faktor perbedaan dan pertentangan keagamaan yang melibatkan kaum Nestorian, Monofosit dan Melchite (aliran ortodoks) mengakibatkan rasa tidak senang dan aman bagi penduduk Mesir, Syiria dan Irak. Dalam kondisi demikian, tidaklah aneh kalau kedatangan orang-orang (tentara-tentara) Islam disambut dengan suka cita sebagai "pembebas" (futubat). Dan sebagian besar berharap bahwa orang-orang Islam dapat menghilangkan penindasan dari Konstantinopel dengan alasan demi menjaga ajaran-ajaran ortodoksi, khususnya masa pemerintahan Justinian (527565). Lihat, Majid Fakhri, A History of Islamic Philosophy, (New York: Colombia, 1970), hlm. $12-13$

${ }^{4}$ Lihat, Howard T. Turner, Science in Medieval Islam, (Austin: The University of Texas Press, 1961), hal. 5. Bahkan tentara Islam mampu menyeberangi pegunungan Pyrene. Tetapi belakangan, ketika pemerintahan Islam di Andalusia tidak pernah sunguh-sungguh lagi untuk menyeberangi pegunungan itu guna menaklukan Prancis. Karena dalam persepsi ummat Islam pada saat itu bahwa daerah-daerah di sebelah utara itu terlalu dingin dan tidak cocok untuk mengembangan peradaban; dan manusianya terlalu kasar dan bodoh. Lihat, Nurcholish Madjid, Kaki langit Peradaban, (Jakarta: Paramadina, 1997), hlm. 10 bandingkan Bernard Lewis, Muslim Discovery of Europe, (New York \& London: W.W. Norton \& Company, 1982), hlm. 8

${ }^{5}$ Musda Mulya, Negara Islam: Pemikiran Politik. Husain Haikal, Jakarta: paramadina, 2001), hlm. 1 
bidang politik. Bahkan Yesus pun bukannya tanpa relevansi politik," dan khususnya "Islam telah memiliki reputasi sebagai agama politik."6 Sedangkan menurut Muhammad Assad, adalah mustahil untuk dapat memperoleh penilaian yang tepat tentang Islam tanpa mencurahkan perhatian sepenuhnya kepada masalah politik. ${ }^{7}$ Karena Islam adalah din wa siyasah (agama dan politik), maka dalam realitas historisnya adalah absurd untuk memisahkan antara agama dan politik. ${ }^{8}$ Bahkan Al-Ghazali menandaskan, "al-din wa al-mulk tau'aman fala yastaghni ahadu-buma min al-akhar (agama dan pemerintahan adalah saudara kembar, yang satu tidak bisa jalan tanpa yang lain) ${ }^{9}$

Sikap Islam memang berbeda dengan agama-agama Yahudi dan Kristen terhadap politik dan negara. Agama Yahudi mula-mula berasosiasi dengan negara, tetapi kemudian berpisah dari negara dan kekuasaan politik. Sementara itu, agama Kristen sudah terpisah dari negara dan kekuasaan politik pada masamasa formatifnya (pertumbuhan awalnya). Sehingga, doktrin agama Kristen menyatakan: "render unto Caesar the thing which are Caesar's; and unto God the thing which are God's" (berikan kepada sang kaisar apa yang menjadi hak kaisar; dan berikan kepada Tuhan apa yang menjadi hak Tuhan). Doktrin semacam ini sama sekali tidak ditemukan dalam ajaran Islam. ${ }^{10}$

Dalam Islam integrasi politik ke dalam agama terlihat jelas dalam ekspresi keagamaan dan politik pada masa Nabi Muhammad, dan selanjutnya dalam banyak hal dilanjutkan dan diiukuti oleh al-Khulafa al-Rasyidin, empat khalifah sesudah Rasul Allah. ${ }^{11}$ Hal yang sama juga terjadi pada kekhalifahan Bani Ummayah dan bani Abbasiyah serta bebrapa kerajaan-kerajaan Islam sesudahnya. Meskipun, praktek politik dan pemerintahan setelah khalifah empat ini berakhir, sulit lagi untuk diklaim secara absah seiring dengan konspesi politik dan kekuasaan yang diperaktek oleh Nabi Muhammad.

Kemudian dalam perkembangannya berikutnya, persoalan politik dengan segala dinamikanya, tentunya senantiasa berlanjut seiring dan inhairen dalam perjalanan sejarah politik ummat Islam. Sehingga, menurut Nurcholish Madjid, memperbincangkan masalah ummat Islam acap kali merambah, secara tak terhindarkan, ke masalah politik dalam Islam. Lebih lanjut Nurcholish Madjid memaparkan:

${ }^{6}$ Lihat, W. Motgemory Watt, Pergolakan Pemikiran Politik Islam, (Jakarta: Beunebi Cipta, 1987), hlm. 32-36

7 Lihat, Salam Azzam (ed.), Beberapa Pandangan tentang Pemerintahan dalam Islam, (Bandung: Mizan, 1990), hlm. 70

${ }^{8}$ Lihat, Azyumardi Azra, Pergolakan Politik Islam, (Jakarta: Paramadina, 1996), hlm. 229.

${ }^{9}$ Lihat, Gustave E. von Grunebaum, Islam Kesatuan Dalam Keragaman, (Jakarta: Yayasan Perhidmatan, 1983), hlm. 217

${ }^{10}$ M. Amin Rais, "Kata Pengantar", dalam John J. Donohue \& John L. Esposito, Islam dan Pembaharuan, (Jakarta: Raja Grafindo Peersada, 1995), hlm. xxi-xxii

${ }^{11}$ Ibid. 
Jika masalah politik selalu muncul dalam berbagai pembahasan tentang Islam, hal itu wajar sekali, dan seharusnya tidak perlu menimbulkan keheranan. Dalam kaitannya dengan masalah politik ini, kaum muslimin bisa mengatakan bahwa agama Islam berbeda dengan agama yang lain. Pernyataan yang sering muncul secara streotifikal itu memang mengandung kebenaran yang substansial. Maka mengingkari hal itu akan berarti sama dengan mengingkari kenyataan sejarah yang telah berabadabad dan yang akan masih berlangsung entah selama berapa abad lagi. Dan tentu hal itu juga berarti sama dengan mengingkari sebagian dari essensi agama Islam. ${ }^{12}$

Pemikiran politik di kalangan umat Islam di masa silam, menurut Hamid Enayat, merupakan salah satu disiplin dalam cakrawala pemikiran khazanah Islam klasik yang ruang lingkupnya tidak terbatas. Bagi pengkaji pemikiran politik, ungkap Hamid Enayat lebih lanjut, akan menemukan dalam sejarah Islam selama enam atau tujuh abad pertamanya suatu mozaik yang mencengangkan dari aliran-aliran pemikiran dan praktek politik dalam Islam. ${ }^{13}$

Dari kenyataan di atas, dalam mencermati hubungan antara Islam dan poltik, khususnya ketatanegaraan, menurut Munawir Sjadzali, umat Islam terbagi dalam tiga aliran pemikiran. Pertama, aliran yang berpendirian bahwa Islam adalah agama yang mengatur totalitas hidup dan menawarkan pemecahan terhadap semua masalah, termasuk dalam masalah politik. Kedua, aliran yang berpendirian bahwa Islam adalah agama semata, termasuk tidak ada hubungannya dengan politik. Artinya, Islam hanya mengatur hubungan antara manusia dan Tuhan. Ketiga, aliran yang berpendirian jalan tengah dari dua aliran sebelumnya. Menurut aliran ini bahwa dalam Islam tidak terdapat sistem

12 Realitas faktual tersebut telah manjadi salah satu temuan terpenting dalam kajian ilmiah tentang Islam, termasuk oleh mereka yang non-Muslim yang kadang-kadang simpati dan kerap kali antipati. Maka Marshall Madgson, misalnya, sebagimana dikutip oleh Nurckholish Madjid, melihat keseluruhan sejarah Islam sebagai "venture" [dijadikan judul bukunya, The Venture of Islam] atau usaha yang tidak kenal berhenti untuk mewujudkan masyarakat yang dicita-citakan. Dan "venture" itu melibatkan orang-orang Muslim dalam praktek semua bidang kehidupan, dengan sendiri juga bidang politik. Lihat, Nurcholish Madjid, "Pengatar" dalam H. Munawir Sjazali, Islam dan Tata Negara, Jakarta; UI-Press, 1990), hlm. v;

${ }^{13}$ Lihat, Hamid Enayat, Modern Islamic Political Thought, (Austin: Univiersity of Texas, t.t.), hal. 4. Di antara aliran-aliran politik yang dimaksud adalah aliran poltik Sunni dan Syi'ah. Paling tidak, perselisiahan kedua aliran poltik itu dapat dilacak berawal dari Balairuang Saqifah Bani Sa'adah, sesaat setelah Nabi wafat yang memperdepatkan tentang kehalifahan. Namun, sesungguhnya yang lebih dapat dipercaya adalah dengan terjadinya tragedi "karbala" yang menjadi "turning point", di saat terbunuhnya cucu Nabi, Husain, secara mengenaskan, bagi pertumbuhan Syi'ah atau Syiisme. Dan perselisihan ini tidak hanya terjadi dan terbatas pada abad ke-6 dan 7 pertama dalam sejarah Islam saja. Lebih lanjut lihat, Sayyid Husain M. Jufri, Islam Syi'ah, (Jakarta: Bulan Bintang, 1991), hlm.14 
politik dan ketatanegaraan. Akan tetapi, Islam mengandung seperangkat tata nilai etik bagi kehidupan bernegara. ${ }^{14}$

Makalah sederhana lebih lanjut ini ingin mengulas pemikiran politik Islam dalam perspektik historis dengan menyorot pemikiran dan sejarah politik Islam pada masa Nabi dan Khulafa al-Rasyidin serta sekelumit pengalaman kerajaan Islam sesudahnya. Lebih jauh makalah ini juga ini dimaksudkan untuk memaparakan ketiga aliran pemikiran politik Islam, seperti pembagian Munawir Sjadzali di atas.

\section{Politik Islam dalam Pentas Sejarah}

Kelahiran agama Islam di tengah-tangah masyarakat Arab jabiliyab ${ }^{15}$ di Mekkah melulu dipandang dari perspektif teologis dan moral dengan

${ }_{14}$ Munawir Sjadzali, Islam dan Tata Negara: Ajaran, Sejarah dan Pemikiran, Jakarta: UIPress, 1990), hlm. 1-2

15 Jahiliyah, akar kata dari "jhl" selama ini senantiasa dikontradiktifkan (sebagai lawan kata) dengan kata "Ilm". Padahal, dalam kebudayaan dan kesusatraan pra-Islam ditemukan kata jhl yang, menurut penelitian Goldziher, arti pokoknya bukan lawan kata ilm (kepintaran), melainkan lawan kata dari hilm. Kata "bilm" dalam bahasa Arab artinya kelamah-lembutan; ketenangan (sakinah); sifat menahan diri dan taqwa, sebagaimana yang termaktub dalam alQur'an: Ketika orang kafir membangkitkan dalam hatinya kesombongan --kesombongan jabiliyah-maka Allah menurunkan ketenangan atas rasul dan mereka yang beriman, dan mewajibkan mereka menahan diri. Dan mereka memang berhak dan patut memilikinya. Dan Allah mengetabui segala sesuatu." (Q.S. al-Fath [48]: 26) Jadi, orang-orang kafir disebut jahiliah bukan kerena mereka tidak berilmu pengetahuan, apa lagi bodoh (tidak pintar). Malah orang-orang Arab pra-Islam sangat masyhur dengan kecerdasan intelektualnya, misalanya ditandai dengan kekuatan hafalannya. Akan tetapi, orang-orang pra-Islam disebut jahiliyah lebih karena mereka tidak dapat menahan diri dan sikap berutal mereka.

Sikap kejam dan tanpa prikemanusia ini dengan jelas tercermin, misalnya, pada diri Khalid bin Walid, ketika ia diutus oleh Rasul untuk menyampaikan misi keislaman dan berdakwah mengajak orang-orang di daerah sekitar Mekkah untuk masuk Islam. Sebelumnya Rasul memerintahkan Khalid bin Walid melaksanakan tugas tersebut secara damai serta tidak melakukan kekerasan dan pertumpahan darah. Tetapi apa yang terjadi, setelah sampai ditujuan, Khalid berseru: "Letakkan senjata, karena setiap orang telah memuluk Islam." Begitu orang-orang di sekitar Mekkah meletakkan senjata, Khalid memerintahkan pasukannya, "ikat tangan mereka ke belakang dan pancung leher meraka." Ketika berita ini sampai di telinga Rasul, ia menyuruh Ali bin Abi Thalib ke sana dan menyelidiki kejadian tersebut serta "memerintahkan agar menghapus semua praktek-praktek jahiliah." Begitu juga, kejadian serupa tampak nyata lima puluh tiga tahun sepeninggalan Rasul, ketika dinasti Umayyah melakukan belas dendam terhadap orang Anshar yang mendukung khilafah Abdullah bin Zubair, sampai tega membombardir kota Madina, memperkosa para gadisnya, membunuh sekitar 80 orang sahabat Rasul dan membunuh sekitar sepuluh ribu orang Anshar dan keturunnanya. Jelas bahwa sikap ini merupakan aspirasi jahiliyah.

Setelah itu, untuk mengelimasi kebobrokan pada masa dinasti Umayyah, dibuatlah konsep baru tentatng jahiliyah dengan menambah kata "zaman." Sehingga kesannya, zaman jahiliyah telah berlalu dengan datangnya Islam. Padahal, jahiliyah tidak terkait dengan "zaman" yang merujuk pra-Islam atau diidentikkan dan didefinisikan dengan masa sebelum 
pertimbangan masyarakatnya adalah pengunut paganisme dan bobrok akhlaknya, an sich. Sementara itu, kelahiran Islam dan tampilnya Muhammad di Mekkah, hampir-hampir tidak pernah dihubungan dengan motif lain, misalnya ekonomi dan politik. Padahal di Mekkah pada masa itu telah terjadi ketimpangan ekonomi-perdagangan dan ketidakadilan politik-kekuasaan. ${ }^{16}$

Mekkah sebagai kota perdagangan ${ }^{17}$ melahirkan konglomarasi yang memenopoli perdanganan, sehingga kekyayaan (modal) terkonsentarisi pada segelintari orang, sekaligus memiskinkan sejumlah banyak orang. Konsekwensinya, menyerat timbulnya ketengangan-ketegangan diantara mereka, dan boleh jadi berakhir dengan peperangan diantara suku-suku yang ada. Dalam kondisi seperti ini, Muhammad tampil untuk memberikan peringatan tentang bahaya yang akan melanda Mekkah beserta perdagangannya. ${ }^{18}$ Maka munculnya Naabi Muhmmad dalam panggung sejarah guna melakukan revolusi dalam rangka merubah tatanan kepercayaan, ekonomi dan politik masyarakat Mekkah. ${ }^{19}$

Namun, selama periode Mekkah (611-622) Nabi Muhammad tidak berhasil mengemban misinya. Ia hanya mendapat pendukung sekelompok kecil dari kalangan yang tidak mempunyai pengaruh serta tidak mempunyai wilayah dan kedaulatan di Mekkah. Posisi mereka pada waktu itu sangat lemah sebagai golongan minoritas tertindas dan tidak mampu menentang kekuasaan kaum Quraisy Mekkah. ${ }^{20}$ Faktor utama kegagalan itu disebabkan Nabi Muhammad

kelahiran Nabi Muhammad. Akan tetapi, jahiliyah lebih merupakan sikap kejiwaan yang tetap ada sampai kedatangan Islam, bakan hingga saat ini,

16 Perolehan harta secara berlebih-lebihan, merampas hak-hak orang lemah dan mengabaikan orang-orang miskin di Mekkah tidak dapat dibenarkan. Karenanya, menurut Watt, ajaran yang mula-mula disampaikan oleh nabi Muhammad sanagat sarat dengan tematema tersebut, seperti tulisnya, " surah-surah yang paling awal dalam al-Qur'an menegaskan bahwa akar dari kegelisahan sosial di Mekkah adalah materialisme indifidualistik kebanyakan penduduknya. Kesombongan saudagar-saudagar besar melalui kekayaannya terhadap orangorang miskin dan tertindas mendapat kecaman. Bahkan ajaran-ajaran teologis dalam surahsurah awal ini mempunyai relevansi dengan situasi tersebut. Lihat, W. Montgemory Watt, Kejayaan Islam: Kajian Kritis Tokob Orientalis, Jokyakarta: Tiara Wacana), hlm. 3-4

17 "Setiap orang Araab, khususnya di Mekkah, kalau bukan seorang pedangan maka ia seorang makelar", kata Straff, seorang perwira tentara Romawi yang ikut berperang di jazirah dalam menuliskan pengalamamnya." "Jika mereka diseru menunaikan sholat Jum'at," demikian firman Allah, "Bergegaslah kamu mengingat Allah dan tinggalkan jaua-beli." (Q.S. 62:9). Dikalangan orang Mekkah, hari Jum'at adalah hari suka-cita dan orang-orang pada sibuk di pasar. Ada hadis Nabi yang mengisahkan, betapa Nabi Muhammad sedang berkhotbah, ditinggalkan jama'ah dan yang tersisa hanya dua belas orang, gara-gara mereka menyambut kafilah yang tiba membawa dagangan. Lhiat, H. Fuad Hashem, Sirah Muhammad Rasulullab: Suatu Penafsiran Baru, Bandung: Mizan, 1990), hlm. 55

${ }_{18}$ Lihat, M.A. Shaban, Sejarah Islam: Penafssiran Baru 600-750, Jakarta: Raja Grafindo Persada, 1993), hlm. 1-9

19 Bernard Luwis, The Political Language of Islam, (Chicaco: University Chicaco Press, 1989), hlm. 92

${ }^{20}$ J. Suyuthi Pulungan, Prinsip-prinsip Pemerintahan dalam Piagam Madinah, (Jakarta: Raja Grafindo Persada, 1996), hlm.1 
dan pengikutnya mendapat tantangan dari kaum Quraiys, kelompaok penguasa Mekkah yang ingin mempertahankan status qua. Bahkan musuh-musuhnya yang kaya itu melakukan pemboikotan ekonomi. Karena di Mekkah tidak kondusif untuk melakan perbaikan, dan malah kesalamatan jiwanya dan pengikutnya terancam, maka mereka tidak mempunyai alternatif, kecuali meninggalkan tanah kelahirannya ${ }^{21}$ untuk hijrah ke Yastrib (belakangan diganti namanya menjadi kota Madinah). ${ }^{22}$

Ketika berada di kota Madinah, Nabi Muhammad membangun sebuah komunitas baru 23 dengan mempersatukan kaum Muhajirin dan kaum Anshar dalam ikatan persaudaraan berdasarkan iman. ${ }^{24}$ Di kota ini, menurut Harun Nasution, umat Islam mempunyai kedudukan yang baik dan segera berkembang menjadi suatu komunitas kuat dan mampu berdiri sendiri. Nabi sendiri menjadi pemimpin masayakat yang baru dibentuknya itu, dan akhirnya menjadi sebuah negara yang wilayahnya kekuasaannya, ketika Nabi wafat, meliputi seluruh kawasan semenanjung Arabiah ${ }^{25}$ Untuk itu, dengan sendirinya, ungkap T. Strothmsann, sebagaimana dikuti oleh Harun Nasution, kapasitas dan peranan yang disandang oleh Nabi Muhammad menjadi ganda: sebagai Nabi dan kepala negara. ${ }^{26}$ Bahkan pada periode Madinah ini, menurut penilaian Philip K. Hitti, unsur kenabian dalam dirinya surut kebalakang, dan sikap politis-praktisnya yang mencuat kepermukaan. ${ }^{27}$

Perjuangan Nabi Muhammad dalam membangun komunitas baru di Madinah acapkali ditunjuk sebagai awal berdirinya organisasi politik dalam Islam. Fazlur Rahaman, tokoh Neo-modernisme Islam asal Pakistan, misialnya menyebutkan bahwa masyarakat Madinah yang dipimpin oleh Nabi

${ }^{21}$ M.A. Saban, Sejarah Islam..., hlm. 12

22 Semua yang dilakukan oleh Nabi Muhammad saw. di kota hijrah itu adalah refleksi dari ide yang terkandung dalam perkataan Arab "madinah". Dari segi etimologis kata ini berarti "tempat peradaban", yaitu padanan perkataan Yunani "polis", seperti dalam nama kota "Constantinopel". Dan "madinah" dalam arti itu adalah sama dengan "hadlarah" dan "tsaqafah", masing-masing sering diterjemahkan, berturut-turut "peradaban" dan "kebudayaan". Akan tetapi, secara etimologis mempunyai arti "pola hidup menetap" sebagai lawan "badawih" yang berarti "pola hidup mengembara, nomad. Karena itu perkataan "madinah" dalam peristilahan modern, menunjuk kepada semangat dan pengertian "civil society", suatu istilah bahasa Inggris yang berarti "masnyarakat sopan, beradab dan teratur dalam bentuk negara yang baik. Lihat, Nurcholish Madjid, Islam Agama Kemanusian, (Jakarta: Paramadina, 1995), hlm. 187

23 Abdullah al-Ahsan, Ummah or nation? Identitas Critis in Contemporary Muslim Society, (The Islamic Foundation, 1992), hlm. 9

24 Hakim Javid Iqbal, "Konsep Negara Dalam Islam”, dalam Mumtaz Ahmad (ed.), Masalah-masalah Teori Politik Islam, (Bandung: Mizan, 1996), hlm. 60

${ }^{25}$ Harun Nasution, Islam Ditinjau dari Berbagai Aspeknya, (Jakarta: UI-Press, 1986), hlm. 92

${ }^{26}$ Ibid., hlm. 3. Lihat juga, Thomas W. Arnold, Tha Caliphate, (London: Routledge and Kegan Paul, 1965), hlm. 30

${ }_{27}$ Philip K. Hitti, History of the Arab, London: Macmillan, 1970), hlm. 116 
Muhammad tersebut merupakan sebuah negara. ${ }^{28}$ Pandangan serupa dari D.B. Macdonald yang menyatakan bahwa di kota Madinah telah terbentuk negara Islam pertama yang meletakkan dasar-dasar politik bagi penerapan perundangan-undangan islam. ${ }^{29}$

Adapun sumber-sember perundangan-undangan di masa Nabi adalah wahyu ilahi dan ketetapan-ketetapannya sendiri. Kalau terjadi sesuatu yang menghendaki adanya ketetapan hukum terhadap peristiwa atau masalah yang terjadi tengah masyarakat, maka Allah menurun kepada Nabi wahyu untuk menjelaskan hukum yang belum diketahuinya. Akan tetapi, bila tidak ada wahyu yang turun maka Nabi melakukan tinjauan hukum untuk menentukan ketetapan hukumnya. Hasil ketetapan Nabi ini bersifat mengikat untuk diikuti oleh ummat. ${ }^{30}$

Karena tindakan Nabi dalam penjalankan pemerintahannya senantiasa berdasarkan pada tuntutnan dan bimbingan wahyu, maka para penulis umumnya menyebutkan negara yang dibentuk oleh Nabi adalah negara teokrasi dalam arti kedaulatan ada pada Tuhan. ${ }^{31}$ Meskipun demikian, ada juga dianatar penulis yang kebeatan dengan pandangan ini, karena banyak ayat alQur'an yang memerintahkan Nabi agar melakukan musyawarah dengan ummat. Salah satu diantaranya, "Bermusyawarah kamu dengan mereka dalam berbagai urusan, kemudian apabila kamu telab membulatakan tekad, maka bertawakkallah kepada Allab" [Q.S. Al-Imran:159].32

Dalam menjalankan pemertinahan, khususnya dalam bidang muamalah, Nabi membuat perjanjian tertulis: "Piagam Madinah". Piagam ini oleh kebanyakan penulis dan peneliti sejarah Islam serta pakar pemikiran politik Islam menyebutkan sebagai konstitusi negara Islam pertama. ${ }^{33}$ Piagam Madinah ini merupakan landasan bagi masyarakat yang terdiri dari kaum Muhajirin, kaum Anshar serta orang-orang Jahudi dalam penyelengaraan administrasi dan keamanan di kota Madinah ${ }^{34}$ sebagai ummah wabidah (komunitas tunggal). ${ }^{35}$

${ }^{28}$ Fazlur Rahman, "The Islamic Concept of State", dalam John J. Donahue \& L. Esposito (ed.), Islamic in Transition Muslim Perspective, (New York: Oxford University Press, 1982), hlm. 261

29 D.B. Macdonald, Development of Muslim Theologi, Jurisprudence and Constitutional Theory, (New York: 1903), hlm. 67

${ }^{30}$ J. Suyuthi Pulungan, Prinsip-prinsip Pemerintahan...., hlm. 6

${ }^{31}$ Musda Mulya, Negara Islam., hlm. 4

${ }^{32}$ Hakim Javid Iqbal, Konsep Negara Dalam Islam., hlm. 62

33 J. Suyuthi Pulungan, op.cit., 8; lihat juga, Zainal Abadin Ahmad, Piagam Nabi Muhammad saw. Konstitusi Negara Yang Pertama di Dunia, Jakarta: Bulan Bintang, 1973

${ }^{34}$ Abdullah al-Ahsan, Ummah or nation? Identitas ..., hlm. 19

35 Watt setuju kalau orang-orang Yahudi yang tinggal di Madinah dimasukkan dalam ummah wabidah. Akan tetapi, tidak sedikit ahli sejarah yang keberatan, misalnya R.B. Serjeant, Frederick M. Denny, memasukkah orang-orang Yahudi masukkan dalam komunitas tersebut. 
Perinsip-perinsip penting yang dapat disimpulkan dalam dalam piagam itu adalah: Kedaulatan di tangan Allah dan otoritas keunggulan hukum-Nya; negara Islam Madinah berdasaarkan hukum Islam dan Nabi adalah kepala pemerintahannya. ${ }^{36}$ Perinsip-perisnip lainya yang dikandung dalam piagam Madinah itu, seperti persamaan hak dan kewajiban, musyawarah, keadilan, persaudaraan, kebebasan, hidup bertetangga, toleransi beragama, perdamaian dan pertaahanan, amar makruf dan nabi mungkar, tolong menolong dan membela yang teraniaya, serta ketakwaan. ${ }^{37}$

Begitu pula, Nabi sangat menekankan tentang nilai-nilai kemanusiaan (humanisme), misalanya sangat nyata dalam pidato Hajj al-Wadha' (haji perpisahan), Nabi menyerukan: "Sesungguhnya darahmu (dima), harta bendamu (amwal), dan kehormatanmu (a'rad) adalah suci atas kamu, seperti sucinya harimu (hari suci haji) ini, dalam bulanmu (bulan suci Dzulhijjah) ini dan dinegerimu (tanah suci) ini". Nilai-nilai kemanusiaan itu harus tetap dijaga karena setiap manusia mempunyai nilai kemanusiaan sejagad. ${ }^{38}$ Dalam pidatonya itu, Nabi juga sangat menegaskan pentingnya hak-hak asasi manusia, misalny hak-hak wanita, budak dan buruh. Nilai-nilai kemanusia dan hak asasi manusia itu berulang-ulang Nabi tegaskan menjalang wafatnya. (Ajaran Islam yang ditegaskan oleh Nabi ini, belakangan mempengaruhi gerakan humanisme di Barat. ${ }^{39}$

${ }^{36}$ Hakim Javid Iqbal, Konsep Negara Dalam Islam..., hlm. 62

${ }^{37}$ J. Suyuthi Pulungan, Prinsip-prinsip Pemerintahan..., hlm. 9

38 Firman Allah " Bahwa barangsiapa membunuh suatu jiwa tanpa (kesalahan) membunuh jiwa yang lain atau membuat kerusakan di bumi, maka ia bagaikan membunuh umat manusia seluruhnya, dan barangsiapa menolong hidup suatu jiwa, maka ia bagaikan menolong hidup umat manusia seluruhnya." (Q.S. 5: 27-32)

39 Pengaruh ajaran Nabi ini dapat dilihat pada pemikiran-pemikiran kefilsafatan tentang manusia dari Giovani Pico della Mirandola, salah seorang pemikir humanis terkemuka zaman Rainassance Eropa, ketika ia menyapaikan orasi ilmiah: "Oratio de homanis dignitate (Oration on the Dignity of man)", orasi tentang harkat dan martabat manusia di depan para pimpinan gereja. Pembukaan orasi itu berbunyi: "Saya telah membaca, para bapak yang suci, bahwa Abdullah seorang Arab Muslim, ketika ditanya tentang apa kiranya di atas panggung dunia ini, seperti telah terjadi, yang dapat dipandang paling manakjubkan?" Ia menjawab: "Tidak ada yang dapat dipandang lebih menakjubkan daripada manusia". Dengan panggal tolak ini Gieovani membeberakan paham kemanusiaannya. Meskipun Geiovani kemudian dimusuhi Gereja dan karena tidak tahan kemudian "bertobat". Akan tetapi, pandangannya itu merupakan salah satu fondasi faham kemanusiaan dan keadilan di Barat, yaitu Humanisme Modern. Belakangan, seperti John Lock merumuskan tentang hak-ha asasi manusia, yaitu Liberte (kebebesan), egalite dan propiete (pemilikikan harta). Begitu pula, pendiri Negara Amerika, Thomas Jefferson, seorang humanis besar merumuskan dokumen modern tantang American Declartion of Independence (Deklerasi Kemerdekaan Amerika), pada 6 Juni 1776, berisi penegasan Life, Liberty, and the Pursuit of Happenes. (hak hidup, hak kebebaan, dan hak mengejar kebahagian). Lihat, Nucholish Madjid, Islam Agama Kemanusia, hlm. 182 dan 221; lihat juga Nurcholish Madjid, "The Potential Islamic Doctrinal Resources for the Establishment and Appreciation of the Modern Consept of Civil Society", Makalah, Konferensi Internasioanl tentang "Islam and Civil Society, Massages from Aoutheast Asia", diselenggarakan oleh The Sasakawa Peace Foundation, Jepang, 5-6 November 1999. 
Segera setelah Rasulullah wafat, menurut Harun Nasution, persoalan yang mula-mula mencuat kepermukaan dalam sejarah awal Islam klasik bukannya persoalan teologis, tetapi justru persoalan politik, ${ }^{40}$ yaitu perbedaan pendapat tentang siapa yang akan menjadi pengganti Rasulullah, khalifah, ${ }^{41}$ dalam memimpin orang-orang Mukmin. ${ }^{42}$ Karena Nabi tidak menunjuk

${ }^{40}$ Malahan dari persoalan politik ini akhirnya memunculkan persoalan teologis yang melahirkan aliran Khawarij, Syiah, Mu'tazilah, Asya'ariah dan lain-lainnya. Lihat, Harun Nasution, Teologi Islam, (Jakarta: UI-Press, 1986), Cet. I, hlm 1-11; Bandingkan, Harun Nasution, Islam Ditinjau dari Berbagai Aspeknya, ( Jakarta: UI-Press, 1978), Jilid I, hlm. 92; lihat juga, Philip K. Hitti, History of the Arabs, (London: Macmillan Press, Ltd., 1970), hlm. 139

${ }^{41}$ Arti term Khalifah secara leksikon: Khalifah jamaknya adalah khulafa', khalaif. Term ini dapat berarti "datang setelah" atau "menggantikan". Lihat, Luis Ma'luf Yusai, Al-Munjid fi alLugha wa al-'Alam,(Libanon: Daar al-Masyraq, 1975), cet. XXVI, hlm. 192, Istilah khalifah pertama kali muncul di Arabiah pra Islam dalam suatu prasasti Arab pada abad ke-6 M. Pada prasasti tersebut tampaknya menunjuk kepada semacam raja muda atau letnan yang bertindak sebagai pemilik kedaulatan yang berada di tempat lain. Kata khalifah muncul dua kali dalam al-Qur'an: pertama, mengacu kepada Nabi Adam (baca: surat al-Baqarah: 28); kedua, mengacu kepada Nabi Daud (baca: surat XXXVII: 257). Adapun surah yang disebut belakangan, muncul dalam konsteks dengan membawa kesan kuat mengenai kedaulatan, "Kami telah menciptakan khalifah di atas muka bumi ini," kata Allah kepada Nabi Daud, “bakimilah manusia secara adil.” Jika ditelusuri, bagi kaum Muslim, Daud adalah Nabi sekaligus raja yang mengkombinasikan baik otoritas religius maupun otoritas politik. Kata khalifah juga muncul beberapa kali dalam al-Qur'an dalam dua bentuk pluralnya, yaitu khulafa' dan khala'if. Kedua bentuk plural tersebut muncul dalam konteks dimana keduanya dapat diterjemahkan menjadi "para pengganti", kadang-kadang bertari " para ahli waris" dan "para pemilik" atau bisa juga menjadi "raja-raja muda". Kekhalifahan historis Islam, muncul pertama kali dan sejauh ini yang paling besar dan penting dalam institusi kedaulatan, bermula setelah wafatnya Rasulullah dan pengangkatan Abu Bakar sebagai penggantinya dalam komunitas Muslim. Abu Bakar adalah merupakan khalifah pertama dari rangkaian panjang khalifah. Ada suatu percakapan menarik, direkam dalam beberapa versi oleh para punilis Arab belakangan, isinya kira-kira seperti ini: "Ketika Abu Bakar menggantikan Nabi, ia disebut sebagai kbalifah Rasul Allah, wakil Rasulullah. Kemudian 'Umar ibn Khattab meneruskan [atau juga menggantikannya, dalam bahasa arabnya istakblafabu]. Seseorang datang menghampiri 'Umar dan menyebutnya sebagai khalifah Allah, wakil Allah. Tetapi "Umar membentaknya, dan lantas berkata: "Itu Daud.” Orang itu kemudian menyebut 'Umar kablifah Rasul Allah, wakil Rasul Allah, dan 'Umar berkata: “Tapi itu Abu Bakar, yang sekarang telah wafat.” Lalu orang tersebut menyebutnya sebagai khalifah khalifah Rasul Allah, (wakil-wakil Rasulullah). Lalu "Umar berkata, "Nah, itu baru tepat, tetapi itu akan berkembang lebih panjang lagi nantinya." Orang itu berikutnya bertanya, "Lalu kami harus menyebut anda apa?" "Umar menjawab, "Kau adalah orang yang beriman, dan aku adalah komandanmu, maka panggillah aku 'komandan' kaum beriman." Lebih lanjut lihat, Bernard Luwis, The Political Language of Islam, (Chicaco: University Chicaco Press, 1989), hlm. 63-64

${ }^{42}$ Pada masa awal Islam tidak dikenal term "orang-orang Muslim/Islam" karena alQur'an sendiri tidak mempergunakan term itu dalam dalam menyeru pengikut Nabi. Akan tetapi yang dikenal adalah term "orang-orang mukmin (beriman)" sepertiyang banyak disebutkan dalam al-Qu'an: "ya ayyuha latsina amanu". Umar Ibn Khattab sendiri, seperti telah dsiebutkand alam catata kami sebelumnya, lebih senang dipanggil sebagai amir al-mu'minin (pemimpin orang-orang beriman). Bahkan term "islam" sebagaimana yang dinisbatkan 
penggantinya, belakangan di kalangan para pemerhati dan mengkaji sejarah Islam klasik, khususnya pengkaji pemikiran politik Islam, mereka membangun argumentasi dan rasionalisasi kenapa Rasulullah tidak menunjuk penggantinya.

Jalaluddin Suyuti, kata Hudzaifah, menyatakan bahwa beberapa sahabat meminta Nabi untuk menunjuk dan mengangkat penggatinya. Namun, Nabi menolak untuk berbuat demikian, seraya bersabda bahwa apabila meraka (ummat Islam) memberontak terhadap pengganti yang diangkat oleh Nabi, maka konsekwensi mereka akan dihukum. Seandainya Nabi mengangkat seorang pengganti dan merinci suatu cara tertentu dalam pemilihan, maka cara itulah yang menjadi satu-satunya cara pengangkatan seorang kepala negara, dan ketentuan yang bersifat membatasi itu akan menyebabkan kesulitan besar dalam perkembangan pemerintahan dalam Islam. Jadi dengan tidak menunjuk pengganti dan menentapkan suatu cara tertentu, maka Nabi telah bertindak sesuai dengan jiwa al-Qur'an menganai masalah tersebut. ${ }^{43}$

Al-Qur'an itu sendiri sedikit sekali mengungkap persoalan (pemerintahan) politik. ${ }^{44}$ Mengapa al-Qur'an tidak menjelaskan dasar-dasar kekhalifahan serta syarta-syarat dan sifat-sifat orang yang akan menjadi khalifah? Jawabannya, bahwa al-Qur'an telah menetapkan tiga dasar pemerintahan dalam Islam, yaitu: keadilan, musyawarah dan kepatuhan ulil amri, baik dalam hal-hal yang disukai atau tidak disukai oleh ummat Islam, kecuali ulil amri itu memerintahkan kepada kedurhakaan kepada Allah dan Rasul-Nya, maka dalam keadaan demikian sesorang ulil amri tidak boleh dipatuhi dan pertahankan, artinya dapat diganti.

Lebih jauh, bahkan menurut Abu Zahrah, tidak ada satupun nash yang qath'i atau isayarat yang jelas dari Nabi tentang siapa yang akan menggantikannya. Yang ada hanyalah perintah Nabi kepada Abu Bakar untuk menggantikan menjadi imam shalat sewaktu Nabi menderita sakit menjelang wafatnya. Para pengkaji pemikiran politik Islam melihat bahwa tidak ada relevansi (sebab akibat) antara menjadi imam shalat dan menjadi khalifah. Apabila hal itu merupakan isyarat, kata Abu Zahra, untuk mengangkat Abu Bakar sebagai khalifah, tentu saat itu kasus ini menjadi argumen perdebatan, tetapi teryata tidak terjadi. 45

kepada agama yang dibawah oleh Nabi hadir belakangan. Tidak diketahu secara pasti siapa dan kapan penyebutan "agama Islam" pertama kalainya.

${ }^{43}$ Lihat, Mumtaz Ahmad, Masalah-masalah Teori..., hlm. 63

${ }^{44}$ Lihat, Nasih N. Ayubi, Political Islam: Religion and Politics in The Arab World, (London: Reutledge, 1991), hlm. 1-2. Mengapa al-Qur'an tidak menjelaskan dasar-dasar kekhalifahan serta syarta-syarat dan sifat-sifat orang yang akan menjadi khalifah? Jawabannya, bahwa alQur'an telah menetapkan tiga dasar pemerintahan dalam Islam, yaitu: keadilan, musyawarah dan kepatuhan ulil amri, baik dalam hal-hal yang disukai atau tidak disukai oleh ummat Islam, kecuali ulil amri itu memerintahkan kepada kedurhakaan kepada Allah dan Rasul-Nya, maka dalam keadaan demikian sesorang ulil amri tidak boleh dipatuhi dan pertahankan, artinya dapat diganti.

45 Sebagian orang kemudian menafsirkan bahwa perintah itu mengisyaratkan sebagai hak Abu Bakar atas kekhalifahan kaum Muslim. Namun, penafsiran semacam ini tidak 
Begitupun, kalau ada hadis Nabi (baca: Hadist Khadir Khum) yang menyatakan pengangkatan Ali bin Abi Thalib sebagai pengganti Rasulullah kelak $^{46}$, itupun dipertanyakan keabsahanya. Menurut M.A. Shaban, salah satu keberatan dan penolakan terhadap hadist pengangkatan Ali sebagai pengganti Rasulullah adalah bahwa pada waktu itu di kalangan orang Arab tidak ada tradisi mengankat pemimpin yang masih berusia muda, sekitar 30-an tahun; dan Nabi Muhammad sangat memahami, sebagai anak zamannya, tradisi orang Arab. ${ }^{47}$

Sebelum jasad Nabi dikebumikan, sejumlah tokoh masyarakan sebagai refresentasi dari kaum Muhajirin dan Anshor melakukan musyawarah ${ }^{48}$ untuk mencari penganti Nabi sebagai khalifah, kepala negara, 49 (dan tentu saja, Muhammad sebagi Nabi tak tergantikan dalam doktrin Islam). ${ }^{50}$ Dalam musyawarah yang alot, tanpa dihadiri oleh kaum Bani Hasyim karena dalam kedukaan mengurus jenasah Nabi, akhirnya terpilih Abu Bakar atas usulan Umar Ibn Khattab. ${ }^{51}$

proporsional, karena pengaturan urusan dunia berbeda dengan urusan ibadah (baca: shalat). Karenanya, isyarat tersebut menjadi kabur. Tambah lagi, dalam perdebatan yang terjadi di antara kelompok Muhajirin dan Anshar di Balairuang Saqifah Bani Sa'adah mengenai khalifah (pengganti Rasulullah) tidak satupun dari kedua kelompok itu yang menjadikan perintah Nabi kepada Abu Bakar untuk menggantikan Nabi menjadi imam shalat sebagai dasar argumen pemikiran, khususnya dari kelompok Muhajirin. Lihat, Muhammad Abu Zahra, Aliran Politik dan Aqidah Dalam Islam, (Jakarta: Logos Publishing House, 1996), hlm. 23

${ }^{46}$ Di kalangan Syi'ah meyakin ini bahwa lewat hadist tersebut diatas bahwa Nabi telah menunjuk sepupunya sekaligus menantunya, Ali bin Abu Thalib sebagai pengatinya.

47 Lihat, M.A. Shaban, Sejarah Islam: Penafsiran Baru 600 - 750, (Jakarta: Raja Grafindo Persada, 1993), hlm. 21

48 Di kalangan orang-orang Arab, sebelum datangnya Islam, memiliki tradisi bermusayarah lewat lembaga yang disebut "Dewan" (Nadi). Di lembaga ini para tokoh (orang-orang tua) dari suatu suku atau kota bermusyawarah untuk memilih pemimpin di kalangan mereka, disamping bermusyawarah mengenai urasan-urasan mereka. Lembaga inilah yang, menurut Fazlur Rahman, kemudia didokratisasikan oleh al-Qur'an dengan menggunakan istilah "syura". Fazlur Rahman, "The Islamic Concept of State" ..., hlm. 263

49 Di kalangan pemikir poltik Mulsim modern, misalnya Ali Abdul Raziq, keberatan tentang peran ganda Nabi tersebut. Baginya, Muhammad hanyalah seorang nabi. Misalnya, disebutkan bahwa Muhammad tidak pernah dinyatakan oleh Al-Qur'an sebagai "Nabi-Raja". Nabi Muhammad tidak diangkat dengan cara demikiran oleh Allah seperti halnya nabi Daud, yang secara khusus di angkat sebagai wakil Allah di bumi. Meskipun demikian, ada banyak alQur'an yang memerintahkan Nabi untuk bermusyawarah dengan ummat Islam. Salah satu contohnya, misalnya tersebut dalam surah Al-Imran: 159, "Bermusyawarahlah dengan mereka dalam berbagai urusan, kemudian apabila kamu telah membulatkan tekad, maka bertawakkallah kamu kepada Allah." Negara di Madinah dibentuk berdasarkan perjanjian; yang dengan perjanjian itu pihak-pihak yang terlibat di dalamnya setuju menjalankan pemerintahan dengan Nabi Muhammad sebagai satu-satunya "wasit" dan sebagai puncak kedaulatan yang dideligasikan. Lihat, Ali Abdul Raziq, Khilafah dan Pemerintahan Dalam Islam, (Bandung: Pustaka, 1985), hlm. 99-109

${ }^{50}$ Harun Nasuition, Teologi ..., hlm. 3

51 Setelah wafatnya Rasulullah, kaum Muslim di Madinah terbentuk kelompokkelompok politik yang berbeda-beda, seperti kelompok kaum Anshar, Muhajirin dan 
Segera setelah Abu Bakar al-Shiddiq terpilih sebagai khalifah, Umar Ibn Khattab memintanya untuk mengulurkan tangannya sebagai wujud menerima jabatan khalifah tersebut. Kemudian Umar Ibn Khattab memberikan Bay'ah ${ }^{52}$ (sumpah setia) kepada Abu Bakar al-Shiddik diikuti oleh kaum Muhajirin dan kaum Anshor. Bay'ah dipahami sebagai kepastian hak dan kewajiban timbal balik antara rakyat dan pengusa (dewasa ini sering disebut sebagai "kontrak sosial"). ${ }^{53}$ Proses pemilihan Khulafah al-Rasyidin berikutnya, masing-masing Umar Ibn Khattab (634-644), Utsaman bin Affan (644-656) dan Ali bin Abi Thalib (656-661) tetap lewat proses musyawarah, meskipun dengan pola yang berbeda-beda yang dilanjutkan dengan bay'ah.

Para Khulafa al-Raysidin, karena bukan seorang Nabi yang menerima wahyu, dalam menjalankan pemerintahan mereka tunduk pada pada prinsipprinsip dasar yang digariskan oleh al-Qur'an dan Sunnah, di sampping mereka

kelompok Bani Hasyim. Masing-masing kelompok mempunyai pimpinan tersendiri. Kelompok kaum Anshar dipimpin oleh Sa'ad bin Ubaidah, kelompok Muhajirin mendudukung Abu Bakar al-Sidik dan Umur ibn Khattab, sedangkan kelompok Bani Hasyim mendukung sepupu dan menantu Nabi, Ali bin Abi Tahlib. Adanya friksi-friksi politik tersebut dengan sendiri menimbulkan pemikiran di bidang politik. Misalnya, kelompok kaum Anshor mengklaim kekuasaan adalah milik mereka dengan pertimbangan bahwa mereka merupakan bagian terbesar dari angkatan bersenjata ummat Islam. Bahkan ketika perdebatan di antara kelompok-kelompok tersebut memuncak dan sulit untuk menemukan kata sepakat, maka kelompok kuam Anshar mengusulkan, sebagai pemikiran alternatif, agar kekuasaan dan kedaulatan ummat Islam dibagi dua. Sebaliknya, kelompok dari kaum Muhajirin berpendapat bahwa kesatuan dan keutuhan kekuasan dan kedaulatan umat Islam harus dipertahankan. Dan dalam kekuasaan dan kedaulatan ummat Islam yang utuh tersebut, menurut mereka, kelompok kaum Muhajirin adalah pemilik kekuasaan yang absah dengan alasan bahwa bagi semua orang Arab hanya mau menerima kepemimpinan dari suku Quraisy saja. Sementara itu, belakangan Bani Hasim mengklaim bahwa kekuasaan dan kepemipinan atas ummat Islam adalah milik mereka dengan pertimbangan atas pertalaian keluarga dengan Rasulullah. Kedua kelompok yang disebut duluan, berkumpul di balairuang Bani Sa'adah dan mengadakan perdepatan politik, seperti disebutkan diatas. Akhirnya, dalam perdebatan kedua kelompok tersebut menyetujui terpilihnya kepemimpinan Abu Bakar atas usul Umar ibn Khattab. Hakim Javid Iqbal, Konsep Negara ..., hlm. 63-64

52 Al-Qur'an mempeergunakan istilah bay'ah untuk janji setia kepada yang diberikan kepada nabi oleh Muslim awal dalam melaksanakan ajaran-ajaran Islam dan membantu nabi. Janji itu diikrarkan oleh orang Mukmin seeraya melatekkan tangannya ke tangan nabi. Ibn Khaldun (wafat 808 H./1406) mengatakan bahwa "bila seorang Muslim memberikan bay'ah kepada pengusa dan berjanji akan patuh, mereka meletakkan tangan mereka ditangan penguasa itu. Karena tindakan ini sama dengan tindakan penjual dan pembila bila melakukan transaksi, maka bay'ah (sebuah kata yang diturunkan dari akar kata yang berarti "menjual") disimbolkan dengan pegangan tangan. Fatih Osman, "Bay'ah al-Imam" Kesepakatan Pengangkatan Kepala Negara Islam", dalam Mumtaz Ahmad (ed.), Masalah-masalah Teori Politik Islam, (Bandung: Mizan, 1996), hlm. 81

${ }_{53}$ Maka dalam sambutan terpilihnya, Abu Bakar menyatakan, "saya bahwa saya telah mendapat kekuasaan dari orang-orang mukmin yang memintanya untuk menjalankan ajaran agama dan Sunnah, sehingga sekirannya saya tetap teguh berpegang kepad keduanya maka saya didukung. Akan tetapi, jika saya kedapatan berbuat salah dalam menjalan kedua aturan pokok itu, maka pecatlah saya”. Fazlur Rahman, The Islamic Concept of State. 
juga melakukan musyawarah dengan para sahabat Nabi. Pada umumnya para pemikir politik dalam Islam berpendapat bahwa pemerintahan mereka inilah yang paling ideal dalam Islam. ${ }^{54}$

Setelah periode Khulafau al-Rasyidin berakhir, pemerintahan dalam Islam beralih kepada dinasti Umayyah. Mu'awiyah (661-680) adalah khalaifah yang pertama merubah sistem pemerintahan dalam Islam dari sistem domokrasi menjadi monarki, yaitu dengan mengangkat putranya, Yazid sebagai pengatinya. Ketika dinasti Ummayah digulingkan oleh dinasti Abbasyiah, bukannya pemerintahan bentuk monarki dirubah, tetapi tetap dipertahankan, bahkan pemerintahnya lebih absolut dari dinasti sebelumnya. ${ }^{55}$ Banyak orang menyangkan perubahan sistem pemerintahan tersebut. Bahkan pemikirpemikir pembaharu dalam Islam abad ke-19 dan 20 menyatakan bahwa salah satu penyebab kemunduran ummat Islam adalah lenyapnya pemeritahan Khulafa al-Rasyidin yang bercorak demokratis dan republik itu. ${ }^{56}$

Dengan berlalunya waktu, setelah ummat Islam menjadi pemegang hegemoni dalam berbagai aspek kehidupan, khususnya dalam bidang politik, selama tujuh abad, mulai abad ketiga belas, ditandai dengan invasi pasukan Tartar dari kerajaan Mongolia tahun $1258,{ }^{57}$ peradaban dunia Islam mengalami

${ }^{54}$ Pemerintahan ideal ini pada masa Khulafa al-Rasyidin disebut, misalnya oleh Madjid Khaduri, pemerintahan berbentuk nomokrasi karena peranan penting dalam pemerintahan adalah Syariah. Berbeda dengan ini, al-Maududi menyebutnya dengan teo-demokrasi karena disamping syariah yang diwahyukan Tuhan sebagai pemegang kedaulatan tunggal dalam Islam, musyawarah antar-ummat juga mempunyai kedudukan penting. Musda Mulya, Negara Islam..., hlm. 5

55 Sabda Nabi, "Sepeninggalanku kekhalifahan berumur tiga puluh tahun. Sesudah itu, ia akan berubah menjadi kerajaan yang digigit (dipertahnkan secara turun-temurun)." Lihat, Abu Zahra, op.cit., hal. 13. Kendatipun hadis ini diragukan oleh peneliti hadis, lantaran "a historis", karena "kekhalifahan" pada masa hidup Nabi belum tercipta, tetapi baru setelah nabi wafat. Namun, keberatan tersebut mengandaikan keraguan mereka terhadap kekuatan estimasi dari Nabi Muhammad. Dan kalau ditinjau bahwa Muahmmad merupakan Rasul Allah, maka keberatan tersebut menjadi tidak terlalu berarti.

56 Musda Mulya, Negara Islam.

57 Andaikata kota Baghdad tidak diserbu dan dianeksasi oleh pasukan Tartar dari Mongolia di bawah pimpinan Hulaqu Khan tahun 1258; dan andaikata tradisi keilmuan dan pemikiran filosofis Ibn Rusyd tidak berpengaruh dan berkembang di Dunia Barat pada abad ke-13; sarta andaikata bangsa Barat tidak menemukan jalur perdangan laut pada abad ke-15, entah seperti apa spektakulernya dunia Islam saat ini. Sayangnya, ini hanya pengandaian. Dan sejarah tidak bisa diajak berandai-andai. Sejarah adalah fakta dan realita yang telah terjadi -yang karena itu ia disebut sejarah. Dan jarum jam sejarah tidak dapat diputar mundur. Ketika relaitas faktual tersebut, telah merubah peta politik dan intelektual dan ekonomi secara global. Sejak kejadian tersebut, dunia Barat telah mengambil alih kedigjayaan dunia Islam di mana dunia Islam sebelumnya merupakan pemegang hegemoni dalam ketiga bidang tersebut selama berabad-abad. Jatuhnya kota Baghdad ke tangan bangsa Mongolia, memang tidak membuat seluruh aktifitas intelektual dunia Islam berhenti, tetapi secara politis, pemerintahan dunia Islam menjadi lemah karena tidak lagi bersifat sentrafugal, tetapi sudah bersifat sentrapetal. Kekalahan secara politis, pada gilirannya berimplikasi pada menurun dan mandeknya keilmuan dan ekonomi di dunia Islam. Lihat, Syed Muhammad Nasir, Islam Its 
Al-Fikra: Jurnal Ilmiah Keislaman, Vol. 5, No. 1, Januari-Juni 2006

stagnasi dan kemunduran. ${ }^{58}$ Kemunduran tersebut memang tidak mutlak dan seragam di dunia Islam. ${ }^{59}$

\section{Penutup}

Dalam penilaiannya terhadap sistem politik yang dibangun oleh Nabi Muhammad, kemudian diteruskan oleh para Khulafa al-Rasyidin, menurut Robert N. Bellah, ${ }^{60}$ sangat modern untuk ukuran zaman dan tempatnya,

Concepts and History (New Delhi: Lahoti Fane Art Press, 1981), hlm. 212; lihat juga, Anwar G. Chejne, Muslim Spain Its Hitory and Cultur (Minneapolis: The Universty of Minnesita Press, 1974) hlm. 328; Seyyed Hossein Nasr, Science and Civilization in Islam, (Cambridge: Harvard University Press, 1968), hal. 312; lihat juga, Malik Bin Nabi, Membangun Dunia Baru Islam, (Bandung: Mizan, 1994). hlm. 11

58 Sebetulnya, kondisi yang memilukan ini tidak perlu terjadi, kalau sekiranya umat Islam, misalnya mau menyahuti seruan gagasan beberapa pembaharu Islam, khusunya, seperti Muhammad Abduh dari Mesir dan Sir Sayyid Ahmad Khan dari anak benua India-Pakistan, untuk mempu menangkap kembali ajaran Islam yang lebih kreatif, dinamis dan logis sekaligus lebih otentik serta mampu menangkap "api Islam" dan meninggkalkan "abunya" sebagaimana yang pernah diperagakan dalam sejarah Islam klasik selama berabad-abad. Namun, kenyataan faktualnya tidaklah demikian, jangankan menangkap sprit Islam, umat Islam justru meninggalkan ajaran Islam. Karenanya, Muhammad Abduh benar ketika mengatakan, "Ummat Kristen maju karena meninggalkan agamanya; dan umat Islam mundur kerena meninggalkan agamanya." Jika direnungkan lebih mendalam ungkapan Muhammad Abduh ini, maka akan menghasilkan argumen bahwa menjadi rasional dalam Islam adalah bagian dari agama itu sendiri, sedangkan pada orang Barat adalah tantangan terhadap agamanya. Jika alur logika ini diteruskan, maka argumen berikutnya bahwa menjadi modern dan ilmiah dalam Islam adalah konsisten dengan ajaran agama Islam sendiri, sedangkan pada orang Barat berarti penyimpangan dari agama. Karenanya, sangat logis dan relevan kalau Sayyid Amier Ali mengungkapkan bahwa Islam bukanlah agama yang membawa kepada kemunduran, tetapi sebaliknya, Islam adalah yang membawa kepada kemajuan. Dan untuk membuktikan hal tersebut, dia kembali merujuk ke dalam sejarah kegemilangan umat Islam klasik. Maksud Sayyid Amier Ali mengungkapkan kejayaan Islam klasik bukanlah untuk "onanisme" (pemuasan diri) ummat Islam, tetapi yang perlu diambil dari pengalaman historis itu adalah apa yang menyebabkan ummat Islam klasik maju dan apa pula yang menyebabkan setelah itu ummat Islam mundur? Menurut Sayyid Amir Ali, jawabnya adalah menghidupkan ulang sifat liberalisme dan sikap rasionalisme dalam Islam. Ia mengingatkan bahwa umat Islam memampu mencapai puncak peradabannya pada masa khalibah Abbasiah, khususnya pada masa pemerintahan al-Ma'mun dikaraenakan penghargaan kepada kebebasan berpikir dan sifat rasional yang di agungkan. Lihat, Nurcholis Madjid, Kaki Langit Peradaban Islam, (Jakarta: Paramadina, 1997), hlm. 21-22 dan 165; lihat juga, Sayyid Amier Ali, The Spirit of Islam, (Delhi: Idarah-i Adabiyat-i Delli, tt.), hlm. 414; bandingkan dengan Harun Nasution, Pembaharuan Dalam Islam Sejarah Pemikiran dan Gerakan (Jakarta: Bulan Bintang), hlm. 120-121

${ }^{59}$ Meskipun dinasti Abbasyiah di Bagdad berakhir, tetapi sejarah kekuasaan politik Islam tetap bertahan deengan lahirnya tiga kerajaan besar dalam Isalam, yaitu Kerajaan Utsamani di Turki, Kerajaan Safawi di Persia dan Kerajaan Mugha di Indiniea. Harun Nasition, Pembaharuan dalam Islam,..., hlm. 14

${ }^{60}$ Robert N. Bellah, Beyon Belief Esei-esei tentang Agama di Dunia Modern, Jakrata: Paramadina, 2000), hlm. 213 
bahkan terlalu "sangat modern" untuk berhasil, seperti dikutip Nurcholis Majid: "Tidak dapat lagi dipersoalkan bahwa di bawah pimpinan Nabi Muhammad masyarakat Arab telah membuat lompatan jauh ke depan dalam kecanggihan sosial dan kapasitas politik. Tatkala struktur yang telah terbentuk di bawah Nabi dikembangkan oleh para khalifah pertama untuk menyediakan prinsip penyusunan suatu imperium dunia, hasilnya suatu yang untuk masa dan tempat sangat modern. Ia modern dalam hal tingginya tingkat komitmen, keterlibatan dan partisipasi yang diharapkan dari kalangan rakyat jelata sebagai anggota masyarakat. Ia modern dalam hal keterbukaan kedudukan kepemimpinannya untuk dinilai kemampuan mereka menurut landasanlandasan universalistis dan dilambangkan dalam upaya melembagakan kepemimpinan yang tidak turun-menurun. Dari satu segi, kegagalan masyarakat dini tersebut, dan kembalinya mereka pada prinsip organisasi sosial pra-Islam, merupakan bukti tambahan untuk kemodernan eksperimen dini tersebut. Eksperimen itu terlalu modern untuk bisa berhasil. Belum ada prasarana sosial yang diperlukan untuk mendukungnnya."61

\section{Bibliografi}

Ahmad, Zainal Abadin, Piagam Nabi Muhammad saw. Konstitusi Negara Yang Pertama di Dunia, (Jakarta: Bulan Bintang, 1973)

al-Ahsan, Abdullah, Ummah or nation? Identitas Critis in Contemporary Muslim Society, (The Islamic Foundation, 1992)

Ali, Sayyid Amier, The Spirit of Islam, (Delhi: Idarah-i Adabiyat-i Delli, tt.)

Arnold, Thomas W., Tha Caliphate, (London: Routledge and Kegan Paul, 1965)

Ayubi, Nasih N., Political Islam: Religion and Politics in The Arab World, (London: Reutledge, 1991)

Azra, Azyumardi, Pergolakan Politik Islam, (Jakarta: Paramadina, 1996)

Azzam, Salam (ed.), Beberapa Pandangan tentang Pemerintahan dalam Islam, (Bandung: Mizan, 1990)

Bellah, Robert N., Beyon Belief Esei-esei tentang Agama di Dunia Modern, Jakrata: Paramadina, 2000)

Chejne, Anwar G., Muslim Spain Its Hitory and Cultur (Minneapolis: The Universty of Minnesita Press, 1974)

Enayat, Hamid, Modern Islamic Political Thought, (Austin: Univiersity of Texas, t.t.) Sayyid Husain M. Jufri, Islam Syi'ah, Jakarta: Bulan Bintang, 1991)

${ }^{61}$ Nurcholsih Madjid, Islam Agama ...., hal 15-16 
Al-Fikra: Jurnal Ilmiah Keislaman, Vol. 5, No. 1, Januari-Juni 2006

Fakhri, Majid, A History of Islamic Philosophy, (New York: Colombia, 1970)

Gustave E. von Grunebaum, Islam Kesatuan Dalam Keragaman, (Jakarta: Yayasan Perhidmatan, 1983)

Hashem, Fuad, H., Sirah Muhammad Rasulullah: Suatu Penafsiran Baru, Bandung: Mizan, 1990)

Hitti, Philip K., History of the Arabs, (London: Macmillan Press, Ltd., 1970)

Iqbal, Hakim Javid, “Konsep Negara Dalam Islam”, dalam Mumtaz Ahmad (ed.), Masalah-masalab Teori Politik Islam, (Bandung: Mizan, 1996)

Lewis, Bernard, Muslim Discovery of Europe, (New York \& London: W.W. Norton \& Company, 1982)

, The Political Language of Islam, (Chicaco: University Chicaco Press, 1989)

M.A. Shaban, Sejarah Islam: Penafssiran Baru 600-750, (Jakarta: Raja Grafindo Persada, 1993)

Macdonald, D.B., Development of Muslim Theologi, Jurisprudence and Constitutional Theory, (New York: 1903)

Madjid, Nurcholish, Islam Agama Kemanusian, (Jakarta: Paramadina, 1995)

, Kaki Langit Peradaban Islam, (Jakarta: Paramadina, 1997)

, "Pengatar" dalam H. Munawir Sjazali, Islam dan Tata Negara, (Jakarta; UI-Press, 1990)

, "The Potential Islamic Doctrinal Resources for the

Establishment and Appreciation of the Modern Consept of Civil

Society", Makalah, Konferensi Internasioanl tentang "Islam and Civil Society, Massages from Aoutheast Asia", diselenggarakan oleh The Sasakawa Peace Foundation, Jepang, 5-6 November 1999.

Malik Bin Nabi, Membangun Dunia Baru Islam, (Bandung: Mizan, 1994).

Montgemory Watt, W., Kejayaan Islam: Kajian Kritis Tokoh Orientalis, Jokyakarta: Tiara Wacana) 1987) , Pergolakan Pemikiran Politik Islam, (Jakarta: Beunebi Cipta,

Mulya, Musda, Negara Islam: Pemikiran Politik Husain Haikal, Jakarta: paramadina, 2001)

Nasir, Syed Muhammad, Islam Its Concepts and History (New Delhi: Lahoti Fane Art Press, 1981)

Nasr, Seyyed Hossein, Science and Civilization in Islam, (Cambridge: Harvard University Press, 1968) 
Al-Fikra: Jurnal Ilmiah Keislaman, Vol. 5, No. 1, Januari-Juni 2006

Nasution, Harun, Islam Ditinjau dari Berbagai Aspeknya, (Jakarta: UI-Press, 1986) 1978) Islam Ditinjau dari Berbagai Aspeknya, Jilid I( Jakarta: UI-Press, Pembaharuan Dalam Islam Sejarah Pemikiran dan Gerakan (Jakarta: Bulan Bintang) , Teologi Islam, (Jakarta: UI-Press, 1986)

Osman, Fatih, "Bay'ah al-Imam” Kesepakatan Pengangkatan Kepala Negara Islam”, dalam Mumtaz Ahmad (ed.), Masalah-masalah Teori Politik Islam, (Bandung: Mizan, 1996)

Pulungan, J. Suyuthi, Prinsip-prinsip Pemerintahan dalam Piagam Madinah, (Jakarta: Raja Grafindo Persada, 1996)

Rahman, Fazlur, “The Islamic Concept of State”, dalam John J. Donahue \& L. Esposito (ed.), Islamic in Transition Muslim Perspective, (New York: Oxford University Press, 1982)

Rais, M. Amin, "Kata Pengantar", dalam John J. Donohue \& John L. Esposito, Islam dan Pembaharuan, (Jakarta: Raja Grafindo Peersada, 1995)

Raziq, Ali Abdul, Khilafah dan Pemerintahan Dalam Islam, (Bandung: Pustaka, 1985)

Saunders, J.J., A History of Medieval Islam, (London: Reutledge, 1965) Godgson, Marshall G.S. The Venture of Islam Conscience and History in a World Civilization, (New York \& London: The Univrsity of Chicago Press, 1961)

Sjadzali, Munawir, Islam dan Tata Negara: Ajaran, Sejarah dan Pemikiran, Jakarta: UI-Press, 1990)

Turner, Howard T., Science in Medieval Islam, (Austin: The University of Texas Press, 1961)

Yusai, Luis Ma'luf, Al-Munjid fi al-Lugha wa al-'Alam,(Libanon: Daar alMasyraq, 1975)

Zahra, Muhammad Abu, Aliran Politik dan Aqidah Dalam Islam, (Jakarta: Logos Publishing House, 1996) 